\title{
CAPABILITĂȚI MILITARE DE GENIU PARTICIPANTE LA OPERAŢII PENTRU SPRIJINUL AUTORITĂŢILOR LOCALE ȘI CENTRALE ÎN SITUAȚII DE URGENȚĂ. PREZENT ȘI VIITOR
}

\author{
MILITARY ENGINEER CAPABILITIES PARTICIPATING TO OPERATIONS \\ IN SUPPORT OF THE LOCAL AND CENTRAL AUTHORITIES \\ IN EMERGENCY SITUATIONS. PRESENT AND FUTURE
}

Col. (r) lect.univ.dr. Andrei Th. CONSTANTIN*

\begin{abstract}
Schimbările climatice petrecute în ultimele două decenii, la care se adaugă criza sanitară, generată de virusul SARS-CoV 2, impun autorităților publice centrale și locale să ia toate măsurile și, totodată, să acționeze cu toate resursele avute la dispoziție pentru păstrarea sănătății și vieții populației, precum și pentru protejarea valorilor materiale și culturale ale acesteia. În pofida faptului că Armata României îndeplinește funcții de sprijin, aceasta deține capabilități unice a căror întrebuințare devine indispensabilă pentru gestionarea situațiilor de urgență ${ }^{1}$ civile. Raportat la sarcinile care trebuie executate, pentru limitarea și lichidarea urmărilor provocate de dezastre, structurile de geniu din Armata română reprezintă capabilitatea cea mai adecvată prin faptul că acestea sunt capabile să intervină în majoritatea situațiilor. Cu toate acestea, capabilitătile militare de geniu trebuie perfecționate și adaptate permanent, astfel încât să fie apte să răspundă noilor tipuri de riscuri care se pot ivi.

Climate change over the last two decades, coupled with the health crisis caused by the SARS COV-2 virus, requires central and local public authorities to involve all resources are available to preserve the health and life of the population, as well as for the protection of their material and cultural values. In addition to the fact that the Romanian Army performs support functions, it has unique capabilities whose use becomes indispensable for the management of civil emergencies. Compared to the tasks to be performed, in order to limit and eliminate the consequences caused by disasters, the military engineer structures in the Romanian Army represent the most adequate capability, by the fact that they are able to intervene in most situations. However, the military engineer capabilities must be constantly perfected and adapted so that they are able to respond to the new types of risks that may arise.
\end{abstract}

Cuvinte-cheie: situație de urgență; intervenție în situație de urgență; structuri militare de geniu/capabilități militare de geniu.

Keywords: emergency situation; emergency intervention; military engineer structures/military engineer capabilities.

Considerații privind situațiile de urgență şi intervenția pentru limitarea și eliminarea efectelor acestora

Situația prezentă la care ne raportăm relevă faptul că, în ultimii douăzeci de ani, evenimentele generatoare de situații de urgență apar pe planeta noastră de patru ori mai des.

Oamenii de știință și cercetătorii au descoperit că există o relație directă între încălzirea globală și numărul tot mai mare de dezastre naturale

\section{*Academia Forțelor Terestre „Nicolae Bălcescu”, Sibiu \\ e-mail: cnstntnandrei@yahoo.com}

de pe planeta noastră. Dacă în anii '80 au apărut anual 120 de dezastre naturale în lume, în prezent numărul dezastrelor naturale este de aproximativ 500 de cazuri anual ${ }^{2}$. Mai mult decât atât, de la sfârșitul anului 2019, omenirea se confruntă cu o criză sanitară de mari proporții, generată de virusul SARS-CoV 2. Din acest motiv, evenimente de tipul calamităților naturale, sinistrelor grave pot lovi simultan una sau poate mai multe zone ale teritoriului național fără avertisment.

$\mathrm{O}$ analiză a riscurilor care pot genera astfel de situații de urgenţă scoate în evidenţă următoarele tipuri de evenimente: incendii de vegetaţie, precipitații abundente provocatoare de inundații, căderi masive de zăpadă, cutremure, tornade, 
accidente/avarii și explozii tehnologice, alunecări de teren, epidemii/epizootii, eșuarea sau scufundarea unor nave, căderi de obiecte din atmosferă ori din cosmos $^{3}$.

In funcție de amploarea evenimentului, consecinţele acestuia pot fi imprevizibile și pot culmina cu afectarea gravă a vieții și sănătăţii populației, precum și cu producerea de pagube materiale însemnate. Din aceste considerente, majoritatea situațiilor de acest gen necesită o intervenție urgentă pentru a preveni o înrăutățire a lor, deși, uneori, este posibil ca atenuarea să nu fie posibilă, iar structurile chemate să intervină să poată oferi doar îngrijiri paliative pentru consecințele ulterioare.

Abordarea comună, interinstituțională a situațiilor de urgență reprezintă soluția corectă și viabilă. În acest mod, expertiza și capabilitățile sunt reunite, se evită duplicarea eforturilor de ajutorare și, de asemenea, se asigură că asistența răspunde nevoilor celor afectați. Prin urmare, punerea în comun de capabilități permite statului să aibă un răspuns colectiv puternic și coerent. Mai mult decât atât, contribuie la coordonarea activităților de pregătire și de prevenire a dezastrelor și permite schimbul de bune practici. Acest lucru facilitează dezvoltarea continuă a unor standarde comune înalte, permițând echipelor de intervenție să înțeleagă mai bine diferite abordări și să lucreze în mod interschimbabil, atunci când apare un dezastru.

La nivel naţional, prevenirea, monitorizarea și gestionarea situaţiilor de urgenţă se realizează într-un cadru interinstituțional și interdepartamental de către Sistemul Naţional de Management al Situațiilor de Urgență ${ }^{4}$ care are ca principale responsabilități restabilirea stării de normalitate după producerea unui dezastru.

Armata României este parte componentă a Sistemului Național de Management al Situațiilor de Urgență, iar sprijinul autorităţilor locale și centrale în situații de urgenţă civile reprezintă una dintre misiunile de bază ale acesteia ${ }^{5}$. În acest sens, Ministerul Apărării Naționale, pentru îndeplinirea atribuțiilor care îi revin, la nivel central, constituie un comitet ministerial care funcţionează sub conducerea ministrului apărării naționale și, de asemenea, pune la dispoziție structuri capabile să participe la limitarea şi înlăturarea efectelor generate de dezastre.
Sarcinile care pot fi îndeplinite de structurile Armatei României sunt în corelație cu riscurile menţionate mai sus, iar acestea sunt: monitorizarea riscurilor şi pericolelor generatoare de situații de urgență; căutarea şi salvarea persoanelor; evacuarea populaţiei și a bunurilor materiale afectate de dezastre; acordarea asistenţei medicale de urgenţă; participarea la localizarea şi stingerea incendiilor; asigurarea transportului forţelor şi mijloacelor de intervenţie, al persoanelor evacuate şi altor resurse; realizarea de facilităţi pentru cazarea și adăpostirea persoanelor afectate de dezastre; decontaminarea şi depoluarea terenului, echipamentelor şi materialelor; sprijin logistic pentru restabilirea ordinii publice; logistica intervenţiilor; reabilitarea zonei afectate.

Intervenția structurilor Armatei române, pentru limitarea și înlăturarea efectelor produse de evenimentele generatoare de situaţii de urgență, se realizează gradual, pe tipuri de risc potenţial, în funcție de amploarea efectelor produse și cu realizarea unei economii de forțe și mijloace.

Structurile de geniu reprezintă componenta de bază a Forțelor Armate, care pot interveni pentru limitarea și înlăturarea efectelor majorității tipurilor de sinistre ce se pot petrece pe teritoriul țării noastre.

Misiunile sprijinului de geniu şi asocierea lor cu funcţiile de sprijin repartizate Ministerului Apărării, în situaţii de urgenţă

Analiza misiunilor sprijinului de geniu, din perspectiva utilizării capabilităţilor de geniu pentru limitarea şi înlăturarea urmărilor efectelor calamităţilor şi dezastrelor permite asocierea unor misiuni specifice operaţiilor militare cu activităţi desfăşurate pe timpul intervenţiilor în zonele calamitate. Ca rezultat al acesteia, se observă o corespondenţă între misiuni şi funcţiile de sprijin repartizate Ministerului Apărării, în situaţii de urgenţă, generate de dezastre.Această corespondenţă explică faptul că, în tradiţie, în Armata română, structurile de geniu reprezintă principala forţă care poate acționa în aceste situaţii. Totodată, geniştii militari pot acţiona la nevoie şi pentru îndeplinirea altor misiuni nespecifice.

În lista misiunilor sprijinului de geniu, în cele două forme de manifestare (combat support engineering și force support engineering ${ }^{\sigma}$ ), se pot identifica domenii comune participării geniştilor 
atât în cadrul operaţiilor militare, cât şi în situaţii de urgenţă civile. Prin urmare, misiunile sprijinului de geniu îşi găsesc corespondent în funcţiile de sprijin alocate Ministerului Apărării pentru situaţii de urgenţă, generate de calamităţi, și pot lua forma:

- operaţii de cercetare, de identificare, de localizare şi culegere de date şi informaţii despre zonele afectate de dezastre şi calamităţi, monitorizarea pericolelor şi riscurilor generatoare de situații de urgență;

- refacerea căilor de comunicaţie civile şi construcţia căilor de acces provizorii către/dinspre zonele calamitate;

- restabilirea continuităţii căilor de comunicaţie către localități/zone izolate, prin amenajarea punctelor de trecere pe poduri provizorii sau portiţe;

- deblocarea căilor de comunicaţie prin eliminarea efectelor alunecărilor de teren, distrugerea podurilor/blocajelor de gheaţă de pe cursurile de apă îngheţate şi a rămăşiţelor clădirilor/instalaţiilor avariate care pun în pericol siguranţa populaţiei;

- protejarea/consolidarea malurilor/digurilor/ versanţilor/podurilor/lucrărilor hidrotehnice şi hidroenergetice cu sisteme de protecţie şi sprijin;

- amenajarea taberelor pentru sinistraţi, a spitalelor de campanie (puncte sanitare), dislocate în sprijinul populaţiei calamitate;

- amenajarea zonelor de evacuare a sinistraţilor, a punctelor de depozitare a ajutoarelor umanitare (materiale, echipamente, instalaţii);

- activităţi privind purificarea, depozitarea şi transportul apei;

- instalarea şi deservirea mijloacelor şi echipamentelor de furnizare a energiei electrice.

Corespondența dintre misiunile sprijinului de geniu în operațiile militare și funcțiile de sprijin ale Armatei României, în situații de urgență direcționează către oportunitatea întrebuințării, pe scară largă, a capabilităților militare de geniu, pentru limitarea și înlăturarea efectelor generate de dezastre sau de alte sinistre grave.

\section{Capabilități militare de geniu pentru îndeplinirea misiunilor sprijinului de geniu, care pot fi asociate cu funcţii de sprijin repartizate Ministerului Apărării, în situaţii de urgenţă civilă}

Armata României a fost angrenată şi a acționat permanent pentru gestionarea evenimentelor generatoare de situații de urgență, întrebuințând resurse umane și materiale necesare și suficiente pentru revenirea la starea de normalitate. Analiza capabilităților militare care pot fi puse la dispoziție de Ministerul Apărării Naționale, pentru îndeplinirea funcțiilor de sprijin repartizate, relevă faptul că structurile militare de geniu sunt printre cele mai adecvate pentru intervenția în situații de urgență.

Întrebuințarea capabilităților militare de geniu reprezintă un factor determinant pentru limitarea și lichidarea urmărilor provocate de dezastre. Intervenția structurilor de geniu, pentru gestionarea evenimentelor generatoare de situații de urgență, a demonstrat și a validat utilitatea acesteia, cu un impact major asupra revenirii la starea de normalitate și asupra reluării vieții cotidiene de către populația afectată, cele mai semnificative tipuri de intervenții fiind prezentate mai jos:

- construcţia de către militarii Batalionului 3 Geniu „General Constantin Poenaru” a unor poduri militare peste râul Buzău. Acestea au refăcut legătura rutieră dintre provinciile istorice ale țării Muntenia și Moldova, în urma inundaţiilor, produse în vara anului 2005, care au avut ca efect distrugerea podului rutier de beton, peste râul Buzău, în dreptul localității Mărăcineni, situat pe comunicaţia rutieră DN 2-E85. Pentru construcția acestora, militarii au utilizat completul de pod jos metalic PJM-72;

- distribuția de alimente de primă necesitate, apă minerală și pături de către militarii Batalionului 96 Geniu „Cetatea București”, în judeţele Teleorman și Bacău, în vara anului 2005. De asemenea, militarii au participat la evacuarea populaţiei civile din zonele afectate de inundaţii, precum și la evacuarea aluviunilor din gospodăriile individuale;

- evacuarea populaţiei afectate de inundaţii şi a bunurilor materiale ale acesteia de către militarii Batalionului 52 Geniu „TISA”, în vara anului 2005, din judeţul Timiş;

- evacuarea populaţiei şi a bunurilor materiale de către militarii Centrului de Pregătire pentru Geniu „Panait Donici”, în decembrie 2005, ca urmare a alunecărilor de teren, produse în localitatea Ocnele Mari, judeţul Vîlcea;

- deblocarea/degajarea, în iarna anului 2006, de către militarii Batalionului 96 Geniu „Cetatea București", cu ajutorul explozivelor a căilor de comunicație rutiere și feroviare de pe Valea Oltului, 
ca urmare a alunecărilor de teren, produse din cauza unor precipitaţii abundente;

- participarea militarilor Batalionului 72 Geniu „General Constantin Savu” la limitarea efectelor inundațiilor din vara anului 2010 prin construcția podului plutitor de pontoane, utilizând parcul de pod din pontoane PR-71, peste râul Suceava, în localitatea Dornești, pe comunicația DN 17A Siret-Rădăuți;

- participarea militarilor din cadrul Brigăzii 10 Geniu „Dunărea de Jos” la deblocarea căilor de comunicații de pe raza județului Brăila și la salvarea de vieți omenești, în urma căderilor masive de zăpadă din anii 2012, 2014, 2016;

- participarea militarilor Batalionului Nave Treceri Fluviale „Danubius”, în iarna anului 2012, la deblocarea căilor de navigație fluvială, între kilometrul 170 și kilometrul 176, utilizând remorcherul „Eftimie Croitoru”;

- participarea militarilor Batalionului 96 Geniu „Cetatea București” la realizarea infrastructurii pentru instalarea și funcționarea Spitalului Militar de Campanie de la Institutul Ana Aslan, pe timpul pandemiei generate de COVID-19.

$\mathrm{Ca}$ o recunoaștere a capacității ridicate de intervenţie, pentru gestionarea situațiilor de urgență, la data de 01.07.2002 se înființează Batalionul 52 Geniu „Tisa”. Actul de naștere a acestuia este constituit de semnarea, la data de 18.01.2002, de către miniștrii apărării din România, Ucraina, Ungaria și Slovacia a Acordului pentru inființarea unei structuri multinaționale de geniu ${ }^{7}$, capabilă să intervină pentru limitarea efectelor produse de inundații majore în bazinul hidrografic al râului Tisa.

Potențialul structurilor de geniu de a pune la dispoziția autorităților locale și centrale capabilități militare, pe tipuri de riscuri probabile, în vederea limitării şi lichidării urmărilor dezastrelor şi calamităţilor naturale, este unul ridicat și poate viza următoarele activități:

- cercetarea şi monitorizarea pericolelor şi riscurilor specifice pe cursurile de apă, drumuri, lucrări de artă, terenuri extravilane, diguri, maluri etc.;

- evacuarea populaţiei şi a bunurilor materiale din zona afectată;

- amenajarea unor tabere de sinistraţi şi depozite de bunuri materiale;

- amenajarea de platforme și instalarea spitalelor de campanie;
- amenajarea unor platforme de aterizare;

- refacerea/amenajarea unor porţiuni de drum şi/sau a unor lucrări de artă;

- întărirea/consolidarea unor maluri/diguri;

- amenajarea şi deservirea unor puncte de trecere pe suporţi ficşi/poduri plutitoare şi nave fluviale;

- devierea unor cursuri de apă în vederea prevenirii inundării gospodăriilor;

- distrugerea controlată a digurilor, malurilor sau a zăpoarelor de gheaţă pentru împiedicarea formării acumulărilor de apă periculoase;

- degajarea căilor de acces cu ajutorul explozivelor;

- asigurarea cu apă potabilă a populaţiei sinistrate;

- aprovizionarea cu energie electrică.

Tendinţe privind dezvoltarea capabilităţilor militare de geniu pentru participarea la gestionarea situațiilor de urgență

Pentru îndeplinirea sarcinilor aferente misiunii de sprijin al autorităților locale și centrale în situații de urgență civile, este necesar ca Armata României, în general, și structurile de geniu, în particular, să continue procesul de transformare, în vederea realizării capabilităţilor adecvate şi adaptate tuturor riscurilor și pericolelor potențiale la care este supus teritoriul naţional.

Transformarea militară reprezintă un proces complex care vizează, printre altele, și domeniile reorganizării structurale și de înzestrare cu echipamente moderne. Înzestrarea cu echipamente de geniu trebuie să vizeze, în principal ${ }^{8}$ : modernizarea şi perfecţionarea echipamentelor militare existente; producerea/achiziţionarea de noi echipamente degeniu, adaptate mediului operațional contemporan și care să respecte standardele NATO; manevrabilitate și abilitate de nivel ridicat; introducerea pe scară largă a noilor tehnologii în procesul de producție a echipamentelor militare de geniu prin cibernetizare şi robotizare. Dincolo de modernizarea echipamentelor din înzestrarea structurilor militare de geniu, se impune crearea de entități organizaționale, după modelul statelor cu experiență consolidată în domeniul intervenției în situații de urgență.

Un exemplu de bune practici îl constituie Austria, care, în anul 1990, a înființat o structură militară pentru intervenție la dezastre, denumită 
Army Reaction and Disaster Response Unit (ARDRU) ${ }^{9}$. De asemenea, în SUA, US Army Corps of Engineers şi National Guard joacă un rol deosebit de important în intervenţiile la dezastre.

La nivelul Uniunii Europene (UE), s-a luat decizia, în luna iunie 1999, de înființare a unei capabilități apte să intervină la crize militare și civile. Reuniunea miniștrilor de externe, desfășurată în anul 2000, s-a finalizat cu înființarea unui mecanism comun de îmbunătăţire a cooperării în intervenţii de asistenţă şi protecţie civilă ${ }^{10}$. Mecanismul contribuie, de asemenea, la coordonarea activităţilor care revin autorităților naționale în direcția pregătirii și prevenirii dezastrelor, precum și la schimbul de bune practici. Acest lucru facilitează dezvoltarea continuă a unor standarde comune mai înalte, permițând echipelor să înțeleagă mai bine diferite abordări și să lucreze în mod interschimbabil, atunci când apare un dezastru. Ca un activ suplimentar pentru mecanism, UE a stabilit o rezervă europeană de capacități suplimentare („rezerva rescEU”). Rezerva include avioane și elicoptere de stingere a incendiilor și echipamente medicale ${ }^{11}$.

În timpul pandemiei de COVID-19, UE a distribuit zeci de mii de măști de protecție, mănuși medicale și 30 de ventilatoare provenind de la centre strategice de distribuție rescEU, găzduite, în prezent, de 9 state membre ale UE, către țările care aveau nevoie. Pentru a asigura un răspuns mai bun provocărilor viitoare, o nouă legislație privind protecția civilă a UE - în vigoare din mai 2021 conferă UE capacități suplimentare de a răspunde noilor riscuri din Europa și din lume și stimulează rezerva rescEU ${ }^{12}$.

Prin similitudine, la nivelul Armatei României, pe lângă structurile de geniu existente, destinate îndeplinirii cerințelor operaționale ale armatei, pot fi create entități destinate exclusiv intervenției în situații de urgență.

Înființarea acestor structuri va aduce beneficii atât în privința disponibilității capabilităților de geniu pentru intervenție, cât și a promptitudinii reacției pentru limitarea și înlăturarea efectelor dezastrelor. Dispunerea și valoarea acestor structuri vor trebui să respecte principiul teritorialităţii, încadrarea va fi realizată cu militari activi și în rezervă, iar înzestrarea va fi făcută în funcţie de riscurile potențiale ale fiecărei zone geografice. Un alt aspect pozitiv îl reprezintă evitarea afectării capacității operaționale ale structurilor de geniu de bază.

\section{Concluzii}

Intervenția autorităţilor centrale și locale, pentru gestionarea evenimentelor generatoare de situații de urgență, are un rol determinant pentru salvarea de vieți omenești, bunuri materiale și în restabilirea stării de normalitate.

Experiența ultimilor ani ne arată în mod clar că Armata română, prin structurile de geniu în mod special, reprezintă componenta cel mai bine adaptată pentru a răspunde nevoilor populației afectate de dezastre.

Diversitatea și complexitatea riscurilor potențiale impun nevoia adaptării permanente a capabilităților și a modalităților de răspuns, astfel încât pierderile de vieți omenești și pagubele materiale să fie reduse la minimum. Prin urmare, structurile militare de geniu trebuie să parcurgă un permanent proces de ajustare structurală și de înzestrare cu echipamente moderne, pentru a putea face față tuturor tipurilor potentiale de risc, generatoare de dezastre sau de alte sinistre grave.

Crearea de structuri militare de geniu, destinate exclusiv intervenției în situații de urgență, devine o cerință esențială pentru realizarea unei intervenții prompte și oportune, cu consecințe majore în salvarea de vieți omenești și în revenirea la starea de normalitate după dezastre. Structurile nou create ar trebui dispuse și înzestrate în conformitate cu harta potențialelor riscuri cu efect asupra teritoriului național.

\section{NOTE:}

1*** Ordonanța de Urgență nr. 21 privind Sistemul Național de Management al Situaţiilor de Urgență, din 15 aprilie 2004, publicată în Monitorul Oficial nr. 361, din 26 aprilie 2004, art. 2, lit. a).

2 Madhumitha Jaganmohan, Global number of natural disasters events 2000-2020 https://www.statista.com/ statistics/510959/number-of-natural-disasters-eventsglobally, accesat la 19.10.2021.

3 *** Ordonanța de Urgență nr. 21 privind Sistemul Național de Management al Situațiilor de Urgență, din 15 aprilie 2004, publicată în Monitorul Oficial nr. 361, din 26 aprilie 2004, art. 2.

\section{Ibidem.}

5 ***Strategia Militară a României, București, 2021, p. 7.

6 *** Land Force Military Engineer Doctrine, ATP 52 (B), pct. 109, 18 December 2008.

7 *** Revista Armei Geniu nr. 21/2012, Râmnicu Vâlcea, 20012, p. 29.

8 Col.conf.univ.dr. Mircea Vladu (coord.), Inzestrarea forţelor de geniu potrivit cerinţelor războiului viitorului, Editura Universității Naționale de Apărare „Carol I", Bucureşti, 2006, pp. 25-30. 
9 https://www.bmi.gv.at/204_english/start.aspx, accesat la 15.10 .2021 .

10 *** European Civil Protection and Humanitarian Aid Operations, https://ec.europa.eu/echo/what/civil-protection/ mechanism_en, accesat la 15.10.2021.

11 Ibidem.

12 Ibidem.

\section{BIBLIOGRAFIE}

*** Carta Albă a Apărării, 2021.

*** Land Force Military Doctrine, ATP-52(B),

18 December 2008.

*** Strategia Militară a României, București, 2021.
*** Strategia Națională de apărare a țării pentru perioada 2020-2024.

***Ordonanța de Urgență $n r .21$ privind Sistemul Național de Management al Situațiilor de Urgență, din 15 aprilie 2004, publicată în Monitorul Oficial nr. 361, din 26 aprilie 2004.

*** Colecția Revista Armei Geniu, nr. 16-30, Râmnicu Vâlcea, 20012.

Col.conf.univ.dr. Vladu Mircea (coord.), Inzestrarea forţelor de geniu potrivit cerinţelor războiului viitorului, Editura Universității Naționale de Apărare „Carol I”, Bucureşti, 2006.

https://www.statista.com

https://www.bmi.gv.at

https://ec.europa.eu 